\title{
Hubungan Obesitas dengan Kejadian Hipertensi
}

\author{
Ulfa Intan Tiara ${ }^{1^{*}}$ \\ ${ }^{1}$ Fakultas Kedokteran, Universitas Lampung \\ Email: intantiaraulfa17@gmail.com
}

\begin{abstract}
ABSTRAK
Penyakit hipertensi adalah salah satu masalah kesehatan yang banyak terjadi di dunia dengan ditandai jika seseorang memiliki tekanan darah sistolik sebesar $\geq 140 \mathrm{mmHg}$ dan atau tekanan darah diastolik sebesar $\geq 90 \mathrm{mmHg}$, pada pemeriksaan berulang. Prevalensi kejadian penyakit hipertensi di Indonesia mencapai 34,1\% pada tahun 2018. Penyakit hipertensi bagi beberapa orang tidak memiliki keluhan apapun namun jika penyakit hipertensi tidak terkontrol dengan baik maka dapat timbul beberapa komplikasi yang spesifik pada organ seperti otak, mata, ginjal, jantung, pembuluh darah, atau organ-organ vital lainnya. Ada beberapa faktor risiko untuk terjadinya penyakit hipertensi yaitu genetik, usia, jenis kelamin dan gaya pola hidup tidak sehat. Gaya pola hidup yang tidak sehat salah satunya adalah bisa terjadinya berat badan berlebih atau obesitas. Dengan adanya penyakit obesitas pada seseorang diduga memiliki hubungan yang bermakna dengan kejadian hiperensi.
\end{abstract}

Kata kunci: Hipertensi, Obesitas.

\begin{abstract}
Hypertension is one of the most common health problems with systolic blood pressure $\geq 140$ $\mathrm{mmHg}$ and / or diastolic blood pressure $\geq 90 \mathrm{mmHg}$, on repeated examinations. The prevalence of hypertension in Indonesia is $34.1 \%$ in 2018. One of the risk factors for hypertension is excess body weight or obesity. Obesity in a person is thought to have a relationship with the incidence of hypertension.
\end{abstract}

Keywords: Hypertension, Obesity. 


\section{PENDAHULUAN}

Penyakit hipertensi merupakan penyakit yang telah menyerang penduduk sebesar 22\% didunia (WHO, 2014). Angka kejadian hipertensi di Asia Tenggara mencapai 36\%. Di Indonesia hasil dari Riset Kesehatan Dasar (Riskesdas) tahun 2018, Indonesia memiliki prevalensi kejadian hipertensi sebesar 34,1\% (Kementerian Kesehatan, 2019). Jika penyakit hipertensi tidak dapat terkontrol dengan baik, maka dapat menyebabkan gangguan ginjal, serangan stroke serta kebutaan. Hasil dari Riskesdas tahun 2010 menjelaskan bahwa penyakit hipertensi menjadi penyebab kematian nomor tiga setelah stroke dan tuberkulosis dengan jumlah mencapai 6,8\% (Kementerian Kesehatan, 2008). Prevalensi akan semakin meningkat seiring dengan bertambahnya usia.

Faktor risiko hipertensi diklasifikasikan menjadi dua faktor yaitu faktor yang tidak dapat diubah seperti usia, jenis kelamin, genetik dan ras. Faktor yang dapat diubah adalah faktor obesitas, merokok, konsumsi alkohol berlebih, stres dan aktifitas fisik (Depkes RI, 2006).

Obesitas merupakan salah satu faktor risiko yang sering djumpai pada penyakit hipertensi. Tahun 2014, penduduk berusia lebih dari 18 tahun mengalami obesitas sebanyak 600 juta penduduk. Secara keseluruhan jumlah penduduk desa yang mengalami obesitas dapat mencapai angka lebih dari 13\% (WHO, 2015). Sekitar 13\% populasi pada orang dewasa di dunia yakni $11 \%$ laki-laki dan $15 \%$ perempuan mengalami obesitas pada tahun 2016. Prevalensi obesitas di seluruh dunia pada tahun 2014 mencapai lebih dari 1,9 miliar orang dewasa atau 18 tahun keatas dengan memiliki berat badan berlebih (WHO, 2014). Di Indonesia, prevalensi kejadian obesitas terus meningkat pada laki-laki dewasa sebesar $19,7 \%$ sedangkan pada wanita sebesar 32,9\% (Kementerian Kesehatan Republik Indonesia, 2014)

Penyakit hipertensi dengan kejadian obesitas masih sering ditemui. Prevalensi penyakit hipertensi disertai obesitas juga terus meningkat. Menurut beberapa penelitian, obesitas dan hipertensi memiliki hubungan yang bermakna. Dari penelitian Jullaman menjelaskan jika penderita memiliki IMT dengan golongan obesitas akan memiliki risiko sebesar 1,64 kali untuk menderita hipertensi dibandingkan dengan IMT normal (Jullaman, 2008). Berdasarkan dari hasil Riskesdas tahun 2018 bahwa kejadian hipertensi yang meningkat di Indonesia juga diikuti dengan meningkatnya proporsi penduduk indonesia yang mengalami kelebihan berat badan atau obesitas.

\section{PEMBAHASAN}

Hipertensi yaitu saat seseorang memiliki tekanan darah sistolik $\geq 140 \mathrm{mmHg}$ dan atau tekanan darah diastolik $\geq 90 \mathrm{mmHg}$, pada pemeriksaan berulang. Tekanan darah diastolik adalah pengukuran utama yang menjadi dasar penentuan diagnosis hipertensi (American Heart Association, 2014).

Gejala yang dialami pada hipertensi adalah dengan adanya peningkatan tekanan darah atau tergantung pada tinggi rendahnya tekanan darah. Gejala hipertensi yang timbul bisa berbeda, bahkan terkadang penderita hipertensi tidak memiliki keluhan. Namun karena sering kali penderita hipertensi tidak menyadari adanya gejala, hal tersebut dapat timbulnya keluhan pada saat sudah terjadinya komplikasi yang spesifik pada organ seperti otak, mata, ginjal, jantung, pembuluh darah, atau organ vital lainnya. (Kurniawan \& Sulaiman, 2019)

Gejala hipertensi mungkin untuk beberapa orang tidak ditunjukkan pada beberapa tahun. Jika adanya gejala hanya pusing atau sakit kepala. Namun jika pada penderita hipertensi berat, gejala yang muncul dapat berupa sakit kepala, mual dan muntah, gelisah, mata berkunang, mudah lelah, sesak nafas, penglihatan yang kabur, 
telinga berdengung, susah tidur, nyeri dada, rasa berat pada tengkuk, ataupun denyut jantung yang semakin kuat atau tidak teratur (Bujawati, 2012)

Faktor risiko terjadinya hipertensi terdapat dua faktor yaitu faktor yang tidak dapat dikontrol seperti usia, jenis kelamin, genetik (Prasetyaningrum, 2014). Sedangkan faktor yang dapat dikontrol berupa kegemukan (obesitas), konsumsi garam yang berlebihan, kurangnya aktifitas fisik, merokok dan konsumsi alkohol berlebih (Dalimartha, 2008).

Obesitas atau berat badan berlebih merupakan salah satu faktor risiko terjadinya penyakit hipertensi dan dianggap menjadi faktor yang independen yang artinya adalah tidak dipengaruhi oleh faktor risiko yang lain. Seorang laki-laki dapat dianggap menderita obesitas jika jumlah lemaknya melebihi $25 \%$ dari berat badan total sedangkan pada wanita jika jumlah lemak melebihi $30 \%$ dari berat badan total atau kriteria yang paling sering digunakan ialah apabila berat badan melebihi $120 \%$ dari berat badan ideal (Adam, 2005). Obesitas dapat terjadi karena ketidakseimbangan antara asupan energi dengan keluarnya energi dalam tubuh, sehingga dapat terjadinya kelebihan energi yang disimpan di tubuh dalam bentuk jaringan lemak. Gaya hidup yang tidak baik merupakan salah satu faktor untuk seseorang mengalami obesitas (Nugraha, 2009).

Obesitas dapat mengakibatkan terjadinya hipertensi dari berbagai mekanisme yakni secara langsung ataupun secara tidak langsung. Secara langsung obesitas dapat mengakibatkan meningkatnya cardiac output. Hal ini dikarenakan makin besarnya massa tubuh maka makin banyak pula jumlah darah yang beredar dan ini menyebabkan curah jantung meningkat (Sheps, 2005) .Sedangkan secara tidak langsung, obesitas terjadi melalui perangsanan aktivitas sistem sarah simpatis dan Renin Angiotensin Aldosteron System (RAAS) oleh mediator-mediator seperti sitokin, hormon dan adipokin. Hormon aldosteron merupakan salah satu yang berkaitan erat dengan retensi air dan natrium yang dapat membuat volume darah akan meningkat (Nagase, 2009).

Pada umumnya, hubungan hipertensi dengan obesitas memiliki karakteristik dengan adanya ekspansi volume plasma dan meningkatnya curah jantuh (cardiac output), hiperinsulinemia atau resistensi insulin, meningkatnya aktivitas sistem saraf simpatis, retensi natrium dan disregulasi salt regulating hormone (Lilyasari, 2007). Dengan meningkatnya insulin dalam darah ini lah yang mengakibatkan retensi natrium pada ginjal dan tekanan darah akan naik (Morrison, 2006).

Seseorang yang mengalami obesitas atau memiliki berat badan berlebih akan membutuhkan lebih banyak darah untuk bekerja menyuplai makanan dan oksigen ke jaringan tubuh. Hal tersebut akan membuat volume darah yang beredar melalui pembuluh darah akan meningkat, kerja jantung meningkat dan ini yang menyebabkan tekanan darah juga akan ikut meningkat (Sheps, 2005).

Penelitian yang meneliti tentang hubungan obesitas dengan kejadian hipertensi telah banyak dilakukan. Terdapat hasil penelitian yang telah dilakukan membuktikan bahwa obesitas adalah faktor risiko yang paling dominan untuk mempengaruhi terjadinya hipertensi. Dari hasil penelitian yang telah dilakukan oleh (Natalia D, 2015) mengatakan bahwa responden yang memiliki obesitas memiliki risiko untuk terjadinya hipertensi sebesar 2,16 lebih tinggi dibandingkan dengan responden yang normal.

Penelitian lain yang dilakukan oleh (Anggara dan Prayitno, 2013) juga mengungkapkan hal yang sejalan dengan penelitian yang lain bahwa responden yang mengalami obesitas memiliki risiko 51,1 kali lebih tinggi untuk menderita hipertensi dibanding dengan responden yang normal.

Terdapat juga penelitian yang telah dilakukan oleh (Kartika, 2016) dengan yaitu ditemukan bahwa responden dengan berlebihnya asupan lemak maka berisiko 
4,246 kali lebih tinggi untuk mengalami hipertensi dibandingan responden dengan asupan lemak yang rendah. Didapatkan $p$ value 0,020.

Adanya obesitas pada penderita hipertensi akan menentukan tingkat keparahan hipertensi. Semakin besar tubuh seseorang, maka akan semakin banyak juga darah yang dibutuhkan untuk menyuplai nutrisi dan oksigen ke jaringan dan otot lain. Hal ini dikarenakan obesitas meningkatkan jumlah panjangnya pembuluh darah yang akan mengakibatkan meningkatnya resistensi darah yang seharusnya mampu menempuh jarak lebih jauh. Dengan meningkatnya resistensi mengakibatkan tekanan darah menjadi lebih tinggi. Keadaan ini akan menjadi lebih parah oleh sel-sel lemak yang memproduksi senyawa yang dapat merugikan jantung dan pembuluh darah (Kowalski, 2010). Berdasarkan hasil penelitian yang dilakukan juga oleh (Maidatul, 2016) mengatakan bahwa masih banyak masyarakat yang belum sadar akan pentingnya menjaga kesehatan tubuh seperti mengubah pola makan dan olahraga. Hal tersebut yang menyebabkan masih banyaknya penderita obesitas disertai hipertensi.

\section{KESIMPULAN}

Berdasarkan dari uraian diatas, dapat disimpulkan bahwa adanya hubungan antara penyakit obesitas dan hipertensi. Seseorang yang memiliki penyakit obesitas cenderung lebih tinggi memiliki risiko untuk terjadinya hipertensi. Dengan adanya obesitas pada penderita hipertensi yang akan menentukan tingkat keparahan pada penyakit hipertensi.

\section{REFERENSI}

Adam. (2005). Metabolic syndrome and its components in Men. Indonesian Journal of Internal Medicine, 37, 66-69.

American Heart Association. (2014). Heart Disease and Stroke Statistics.

Anggara dan Prayitno. (2013). Faktor-faktor yang Berhubungan dengan Tekanan Darah di

Puskesmas Telaga Murni Cikarang Barat. Jurnal Ilmiah Kesehatan, Vol 5/ No.

Bujawati, E. (2012). Penyakit Tidak Menular, Faktor Resiko dan Pencegahannya. Makassar: Alauddin University Press.

Dalimartha. (2008). Hipertensi. Penebar Plus: Jakarta.

Depkes RI. (2006). Pharmaceutical Care untuk Hipertensi. Jakarta: Departemen Kesehatan RI.

Ihsan Kurniawan, S. (2019). Hubungan Olahraga, Stress dan Pola Makan dengan Tingkat Hipertensi di Posyandu Lansia di Kelurahan Sudirejo I Kecamatan Medan Kota . Journal of Health Science and Physiotherapy, 1(1), 10-17.

Jullaman. (2008). Hubungan Obesitas dengan Kejadian Hipertensi Stage 1 Pada Penduduk Usia Di atas 18 Tahun Yang berkunjung Ke Puskesmas di Wilayah Kabupaten Aceh Tamiang Tahun 2008. Universitas Indonesia.

Kartika. (2016). Asupan Lemak dan Aktivitas Fisik Serta Hubungannya Dengan Kejadian Hipertensi Pada Pasien Rawat Jalan. Jurnal Gizi Dan Dietetik Indonesia, IV (3), 139146.

Kementerian Kesehatan. (2008). Laporan Nasional Riset Kesehatan Dasar (RISKESDAS) 2007. Badan Litbangkes, Depkes RI : Jakarta.

Kementerian Kesehatan. (2019). Buku Pedoman Manajemen Penyakit Tidak Menular. Jakarta: Kementrian Kesehatan Republik Indonesia.

Kementerian Kesehatan Republik Indonesia. (2014). Profil Kesehatan Indonesia Tahun 2013. Jakarta: Kementerian Kesehatan Republik Indonesia.

Kowalski. (2010). Terapi Hipertensi: Program 8 Minggu menurunkan Tekanan Darah Tinggi Dan Mengurangi Resiko Tekanan Jantung Dan Stroke Secara Alami. Bandung: Qanita 
Mizan Pustaka.

Lilyasari. (2007). Hipertensi dengan obesitas adakah peran endotelin. J Kardiol Ind, 28(6), $460-475$.

Maidatul. (2016). Hubungan Obesitas Dengan Hipertensi Pada Masyarakat di Wilayah RW 13 Dusun Mojosari Desa Ngenep Kecamatan Karaploso. Nursing News.

Morrison. (2006). The zucker rat as a model of obesityhypertension. University of Marshall. Huntington, USA.

Nagase. (2009). Mineralocorticoid Receptor Activation In Obesity Hypertension. The

Japanese Society of Hypertension., 32, 649-657.

Natalia D. (2015). Hubungan Obesitas dengan Kejadian Hipertensi di Kecamatan Sintang,

Kalimantan Barat. Skripsi. FK Universitas Tanjungpura. Tanjung Pura.

Nugraha. (2009). Etiologi dan Patofisiologi Obesitas. Jakarta: Sagung Seto.

Prasetyaningrum. (2014). Hipertensi Bukan Untuk Ditakuti. Jakarta: Fmedia.

Sheps. (2005). Mayo clinic hipertensi, mengatasi tekanan darah tinggi. Intisari Mediatama: Jakarta.

WHO. (2014a). Commission on Ending Childhood Obesity. World Health Organization.

Departement of Noncommunicable disease surveillance.

WHO. (2014b). GLOBAL STATUS REPORT on Noncommunicable Diseases.

WHO. (2015). Obesity and Overweight. 